Aftenie C. ${ }^{1}$, Bordeianu I. ${ }^{2}$

\title{
Clinical and histo-pathological aspects of the skin tumours in the nasal region
}

${ }^{1}$ ENT\& Oro-Maxillo-Facial Surgery Department, Constanta County Hospital

${ }^{2}$ Plastic Surgery Department, Faculty of Medicine, "Ovidius" University of Constanta

\begin{abstract}
Nasal pyramid presents an increased frequency of skin tumours such as basal cell or squamous cell carcinomas. That could be explained by the increased rate of solar radiation exposure. Fear of a malign skin disease have been rising public awareness of the danger of exposure to sunlight. However, the incidence of skin cancer is continuously increasing. The probability of developing a skin tumour increases with age. Typically, concern relates to the patient on the cosmetic appearance and on the malignant potential of the lesion. Nasal defects can take place most often after oncological procedures. Knowing the most common forms of benign and malignant skin tumours is crucial for a proper evaluation and therapeutic management. Particular importance should be given to those clinical issues that may raise suspicion of a malignant lesions turn. In this study we evaluated the incidence of nasal pyramid tumours. This included also the pathological aspect of nasal skin.
\end{abstract}

Keywords: skin tumours, nasal defects, basal cell carcinoma, tumour incidence.

\section{Cristian Aftenie}

Clinical Emergency Hospital of Constanta

Tomis Blvd. no. 145, Constanta 900591, Romania e-mail: afteniecristian@yahoo.com

\section{Introduction}

In recent years, skin cancer has reached epidemic proportion. Foundation for skin cancer in the United States estimated that one in six Americans will develop a malignant skin lesion during life [1]. Fear of a malign skin disease have been rising public awareness of the danger of exposure to sunlight. However, the incidence of skin cancer is continuously increasing. Both doctors and politicians in countries with a significant incidence of this skin disorder, such as Australia or the United States, initiated and promoted screening programs at the local, state and national level in order to better disease surveillance rate. The result of implementing these screening programs has been decreasing morbidity and mortality associated with skin cancer [2].

The tumorous processes of the skin increase patient worries and thus addressing frequencies by primary care services, dermatology, plastic surgery. Typically, concern relates to the patient on the cosmetic appearance and on the malignant potential of the lesion[3,4]. Knowing the most common forms of benign and malignant skin tumours is crucial for a proper evaluation and therapeutic management. Particular importance should be given to those clinical issues that may raise suspicion of a malignant 
lesions turn.

\section{Description of patients group}

In the period January 2013 - December 2014 94 patients were treated in the Clinic Otolaryngology - Oro-maxillofacial being diagnosed with tumours in the nasal pyramid. In the study group were enrolled 33 men (35.10\%) and 61 women (64.90\%) seeing a marked difference in the incidence according to sex.

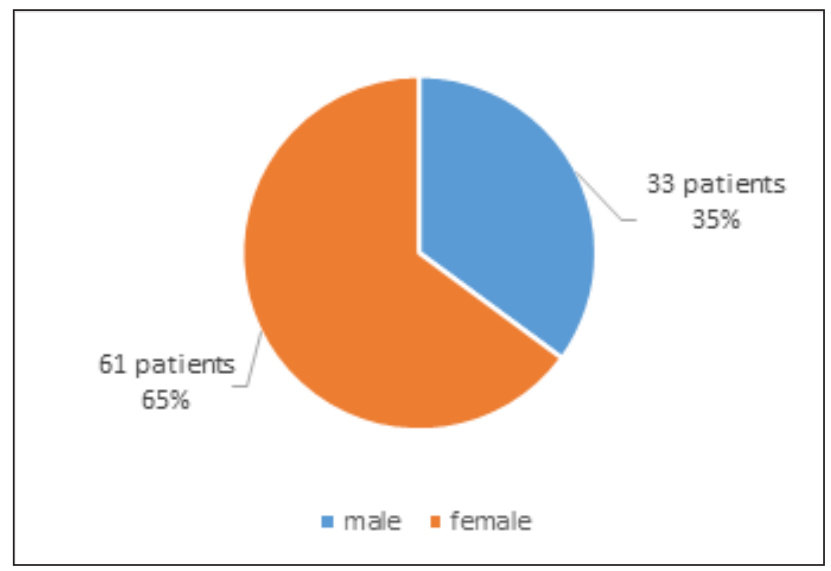

Fig. 1 - Sex distribution of patients

Patients who had been treated were between the ages of 6 and 93 years, with a mean of 68 years.

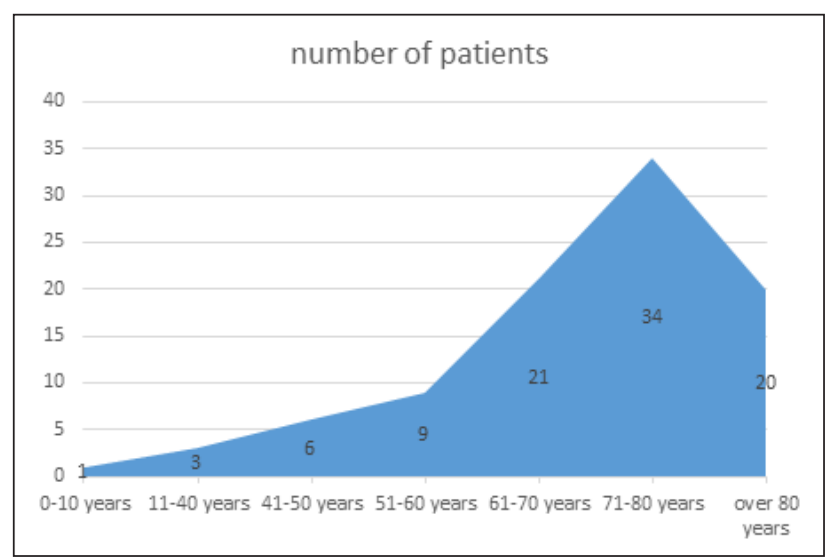

Fig. 2 - Distribution by age of patients
Most patients in the study group were diagnosed in dermatology services $(50 \%)$ by ORL services - OMF $21.27 \%$, the rest being diagnosed by other specialties, including primary care - family medicine $-11.7 \%$.

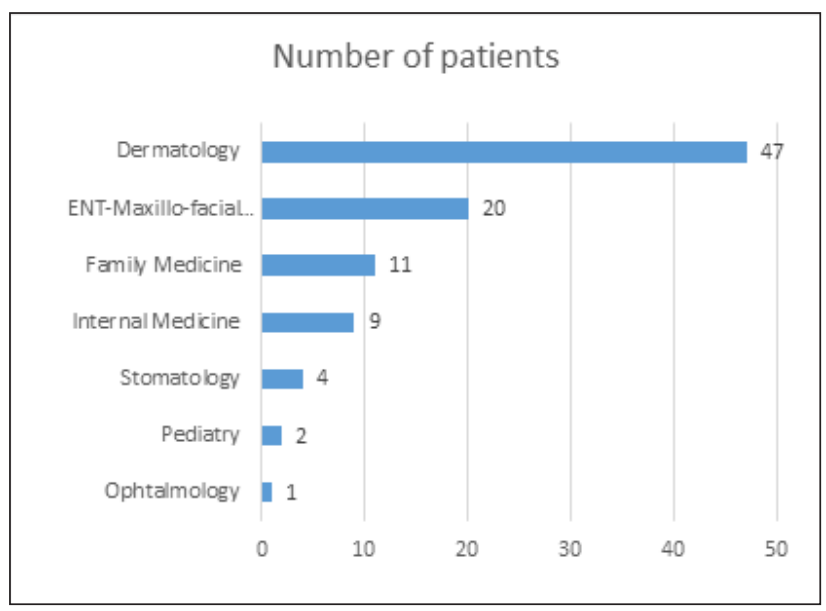

Fig. 3 -Distribution by speciality

Of the 94 patients approximately 48 patients $(51.06 \%)$ are known with other conditions. The remaining 46 patients (48.94\%) are not known at the time of the nose tumour diagnosis with any other condition.

Since many collateral problems were find in the same patient, we had identified 52 illnesses in 94 patients. The most frequently disorders were cardiovascular - 27 cases (51.92\%), followed by diabetes 8 cases (15.38\%), coagulation disorders (6 cases- $11.54 \%$ ) and respiratory disorders 7 cases $13.46 \%$. Other conditions were at a rate less than $8 \%$.

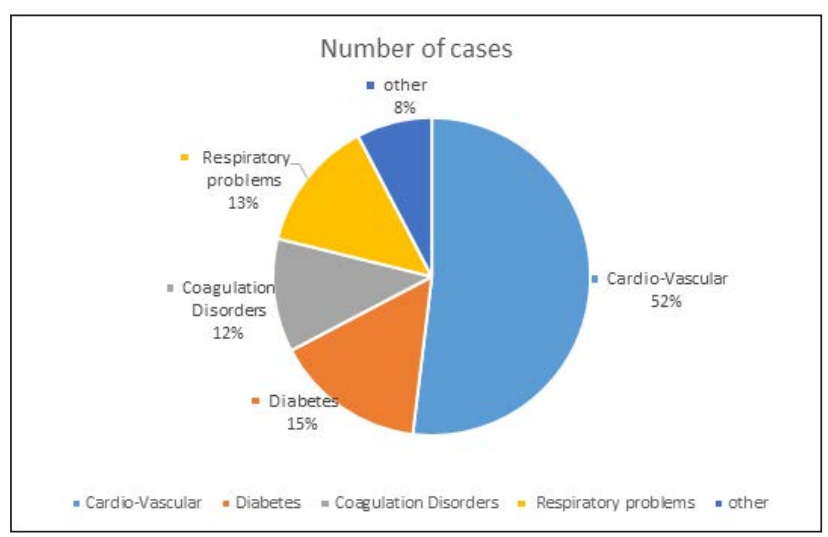

Fig. 4 -Chronic disease find in study group 
Clinical and histo-pathological results

\section{Tumour localisation}

The chart below describes the distribution among patients in this study based on the location of the tumour in the nasal pyramid.

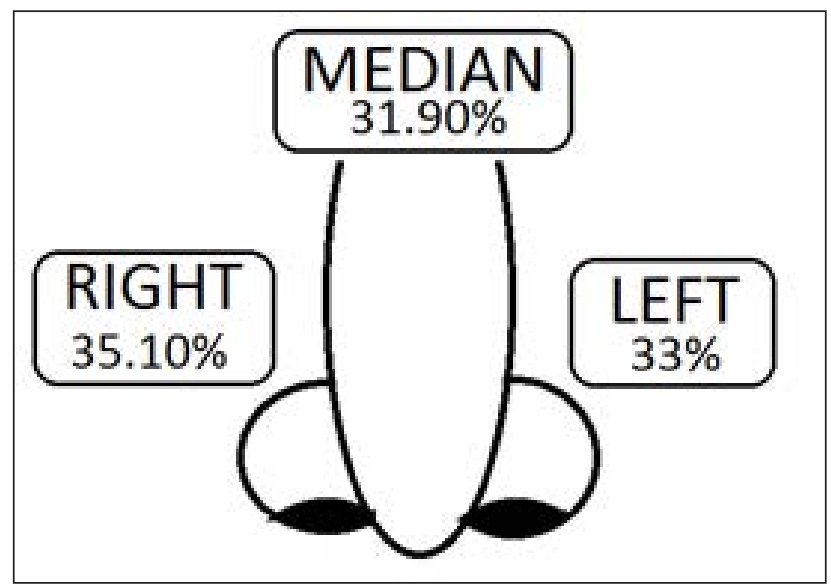

Fig. 5 -Distribution of patients by lesion location

The locations at the right side or left side of the nasal pyramid, differ by only 2 cases ( 33 cases $35.10 \%$ in 31 cases $-33 \%$ ) and tumour location in the

middle region of the nasal pyramid was present only 30 cases $-31.90 \%$.

They were excluded from the study patients who had multiple tumours in the nasal pyramid locations. Thus, they identified a total of 64 patients with tumours in the side regions of the nasal pyramid, and 30 patients had tumour in the middle region.

The table below shows the differences between the incidence of tumours of the nasal pyramid with localization in the dorsal region and nasal wing region $26.3 \%$ respectively $25.9 \%$ of cases. The apex nasal $(16.5 \%)$, the side of the nose $(14.3 \%)$ and naso-labial region $(10.2 \%)$ continue statistics, which is closed by columellar-nostril regions and the nose both under the scope of $4 \%$.

Tabel I - Distribution by lesion location

\begin{tabular}{|l|c|}
\hline Localisation & Percent \\
\hline Root of the nose & $3 \%$ \\
\hline Nostril subregion & $3.8 \%$ \\
\hline Naso-labial subregion & $10.2 \%$ \\
\hline Side of the nose & $14.3 \%$ \\
\hline Tip of the nose & $16.5 \%$ \\
\hline Nasal wing & $25.9 \%$ \\
\hline Dorsal subregion & $26.3 \%$ \\
\hline
\end{tabular}

Tabel II - Distribution of cases according to lesion location and histo-pathological form

\begin{tabular}{|l|c|c|c|c|c|}
\hline TUMOUR type & $\begin{array}{c}\text { Cutaneous } \\
\text { nevi (n=9) }\end{array}$ & $\begin{array}{c}\text { Squamous cell } \\
\text { carcinoma } \\
(\mathbf{n = 6})\end{array}$ & $\begin{array}{c}\text { Actinic } \\
\text { Keratosis } \\
(\mathbf{n = 1 7 )}\end{array}$ & $\begin{array}{c}\text { Basal cell carcinoma } \\
\text { (sclerodermiform) } \\
(\mathbf{n = 1 3 )}\end{array}$ & $\begin{array}{c}\text { Basal cell } \\
\text { carcinoma } \\
(\mathbf{n o d u l a r})(\mathbf{n = 4 5})\end{array}$ \\
\hline LEFT 31 & $2(22.25 \%)$ & $3(50 \%)$ & $4(23.5 \%)$ & $3(23.1 \%)$ & $18(40 \%)$ \\
\hline RIGHT 33 & $5(55.5 \%)$ & $2(33.33 \%)$ & $3(17.7 \%)$ & $6(46.15 \%)$ & $16(35.55 \%)$ \\
\hline MEDIAN 30 & $2(22.25 \%)$ & $1(16.67 \%)$ & $10(58.8 \%)$ & $4(30.75 \%)$ & $11(24.45 \%)$ \\
\hline TUMOUR type & $\begin{array}{c}\text { Cutaneous } \\
\text { nevi (n=9) }\end{array}$ & $\begin{array}{c}\text { Squamous cell } \\
\text { carcinoma } \\
(\mathbf{n}=\mathbf{6})\end{array}$ & $\begin{array}{c}\text { Actinic } \\
\text { Keratosis } \\
(\mathbf{n}=\mathbf{1 7})\end{array}$ & $\begin{array}{c}\text { Basal cell carcinoma } \\
\text { (sclerodermiform) } \\
(\mathbf{n}=\mathbf{1 3})\end{array}$ & $\begin{array}{c}\text { Basal cell } \\
\text { carcinoma } \\
(\mathbf{n o d u l a r})(\mathbf{n}=\mathbf{4 5})\end{array}$ \\
\hline Root of the nose & $1(11.1 \%)$ & 0 & 0 & 0 & 0 \\
\hline Nostril subregion & $2(22.2 \%)$ & 0 & 0 & $1(7.7 \%)$ & $1(2.2 \%)$ \\
\hline $\begin{array}{l}\text { Naso-labial } \\
\text { subreg. }\end{array}$ & $1(11.1 \%)$ & $1(16.6 \%)$ & $1(5.9 \%)$ & 0 & $6(13.3 \%)$ \\
\hline Side of the nose & $1(11.1 \%)$ & $1(16.6 \%)$ & $1(5.9 \%)$ & $1(7.7 \%)$ & $8(17.8 \%)$ \\
\hline Tip of the nose & 0 & 0 & $4(23.54 \%)$ & $2(15.4 \%)$ & $9(20 \%)$ \\
\hline Nasal wing & $1(11.1 \%)$ & $2(33.34 \%)$ & $2(11.76 \%)$ & $4(30.7 \%)$ & $14(31.1 \%)$ \\
\hline Dorsal subregion & $3(33.4 \%)$ & $2(33.34 \%)$ & $9(55.9 \%)$ & $5(38.5 \%)$ & $7(15.6 \%)$ \\
\hline
\end{tabular}


In this study, they were considered relatively high frequency having those types of tumours that have reached a minimum rate of $8.6 \%$. Further attention was paid to cases histological diagnosed as squamous cell carcinoma.

Of patients diagnosed with pigmented nevi, they were located in $50 \%$ of cases the right side $(52.2 \%)$ and in the dorsal region of the nose in $39.2 \%$ of cases.

Half of patients diagnosed with squamous cell carcinoma, had the tumour on the left, while in $18.7 \%$ of cases of squamous cell carcinoma was reached medial region of the nose. It should be noticed that the nostrils region, root of the nose and tip of the nose no patients in the study had squamous cell carcinoma. The dorsal region of the nose and the nasal wing squamous cell carcinoma was found in the same percentage of $31.3 \%$, while the lateral regions of the nose and naso-labial region were interested in a ratio of only $18.7 \%$.

Of all cases of actinic keratosis, more than half $(53.0 \%)$ were diagnosed in the medial region of the nose, while the sides of the nasal pyramid, cases were identified equally by the left and right in $23.5 \%$.

Sclerodermiform basal cell carcinoma was identified in the regions of the nasal pyramid on the right, in the middle and on the left side in a proportion of $41.9 \%, 32.3 \%$ respectively $25.8 \%$.

Finally, the most common histological form, nodular basal cell carcinoma has a higher incidence at the lateral sides of the nose $33.9 \%$ respectively $41.3 \%$ left right), compared with nasal medial region respectively $24.8 \%$. Thus, at the root of the nose there was no case of nodular basal cell carcinoma; $2.5 \%$ of this type of tumour was present in the nostrils regions, compared with the wing of the nose, which have been described in $31.4 \%$ of cases.

Concluding histo-pathological findings obtained in this study, it revealed increased frequency of basal cell carcinoma nodular form (almost half $45 \%$ of all cases) in the nasal pyramid, followed by actinic keratosis ( $12 \%$ of cases) and sclerodermiform basal cell carcinoma (11.6\% of cases). At the other side of statistics, pigmented nevi were located in approximately $8.5 \%$ of the cases, squamous cell carcinoma in $6 \%$. The rest of histo-pathological forms of tumours encountered in the nasal pyramid did not exceed $4 \%$ of all cases.

Table III - Distribution of cases according to diagnosis

\begin{tabular}{|l|c|c|}
\hline $\begin{array}{l}\text { Hstopathological } \\
\text { type }\end{array}$ & $\begin{array}{c}\text { Number of } \\
\text { cases }\end{array}$ & Percent \\
\hline $\begin{array}{l}\text { Basal cell carcinoma } \\
\text { (nodular) }\end{array}$ & 45 & $48 \%$ \\
\hline Actinic Keratosis & 17 & $18 \%$ \\
\hline $\begin{array}{l}\text { Basal cell carcinoma } \\
\text { (sclerodermiform) }\end{array}$ & 13 & $13,8 \%$ \\
\hline Cutaneous nevi & 9 & $9,6 \%$ \\
\hline $\begin{array}{l}\text { Squamous cell } \\
\text { carcinoma }\end{array}$ & 6 & $6,4 \%$ \\
\hline Seboreic Keratosis & 3 & $3,2 \%$ \\
\hline Other types & 1 & $1 \%$ \\
\hline
\end{tabular}

\section{Discussions}

The probability of developing a skin tumour increases with age, as many studies have shown $[5,6]$. The increase in cases of tumour pathology in relation to age was determined by adding several exogenous and endogenous factors $[2,4,7]$.

By far, most patients were directed to the Department of Otolaryngology-Oro-MaxilloFacial Surgery by dermatology services, confirming that addressing the high patient with skin tumour (including the facial region) is the dermatologist [8].

Skin tumours, especially baso-cellular carcinomas are found in up to $80 \%$ of cases in the head and neck [9], with a lower incidence in women compared with men[10].

In the nasal pyramid region, there is an increased frequency of skin tumours such as basal cell or squamous cell carcinomas. That could be explained by the increased rate of solar radiation exposure $[1,11,12]$.

The dorsal and wing nasal sub-regions were diagnosed with tumour proliferation in $50 \%$ of cases. Add to this the rest tumours in the tip of the 
nose to nose, and lateral nasal region and naso-labial regions we have obtained a percentage of $93.2 \%$. This percentage indicates that certain sub-regions of the nasal pyramid are protected from the direct action of some carcinogens - such as ultraviolet rays. Thus, the nostrils region and root of the nose protected by eyebrows region especially in men, are less exposed to direct action of the sun $[13,14]$.

\section{References}

1. Horch, H. (2007). Mund - Kiefer - Gesichtschirurgie. 4. Auflage. München, Jena: Urban \& Fischer - Verlag.

2. Uhlenhake, E.E., Sangueza, O.P., Lee, A.D. \& Jorizzo, J.L. (2010). Spreading pigmented actinic keratosis: a review. J Am Acad Dermatol. 63(3), 499-506. doi: 10.1016/j.jaad.2009.07.026

3. Eskiizmir, G., Gencoglan, G., Temiz, P., Hircin, Z. \& Ermertcan, A. (2011). Staged-surgery with permanent pathology for the management of high-risk nonmelanoma skin cancer of the nose. Eur Arch Otorhinolaryngol. 268(1), 117-121. doi: 10.1007/s00405-010-1324-X.

4. Seretis, K., Thomaidis, V., Karpouzis, A., Tamiolakis, D. \& Tsamis, I. (2010). Epidemiology of surgical treatment of nonmelanoma skin cancer of the head and neck in Greece. Dermatol Surg. 36(1), 15-22. doi: 10.1111/j.15244725.2009.01379.x

5. Emrich, K., Husmann, G., Zeißig, S., Seebauer, G. \& Blettner, M. (2009). Krebs in Rheinland - Pfalz. Inzidenz und Mortalität im Jahr 2006. Bericht des Krebsregisters, 37-40..

6. Schöne, P. (2011). Retrospektive Untersuchung zur Epidemiologie, Ätiologie und Behandlung von Hauttumoren der Nase. Bochum: Dissertation.

7. Hafner, J., Kempf, W., Schmid, M.H., Kurz, M., Urosevic, M., Dummer, R. \& Burg, G. (2002, April 17). Epitheliale Hauttumore - Eine interdisziplinäre Aufgabe für Grundversorger. Schweiz Med Forum, 369-375

8. MacKie, R. (1990). Benigne und maligne
Tumoren der Haut, Ursachen, Histopathologie und Behandlung. Berlin: Hippokrates.

9. Rustemeyer, J., Gunther, L. \& Bremerich, A. (2009). Complications after nasal skin repair with local flaps and full-thickness skin grafts and implications of patients' contentment. Oral Maxillofac Surg. 13(1), 15-19. doi: 10.1007/ s10006-008-0139-z

10. Theissing, J., Rettinger, G. \& Werner, J. (2006). $H N O$ - Operationslehre. Stuttgart: Thieme Verlag.

11. Jewett, B.S. (2007). Repair of Small Nasal Defects. Otolaryngologic Clinics of North America. 40(2), 337-360. doi: 10.1016/j. otc.2006.11.009

12. Duflo, S., Paris, J., Turner, F., Giovanni, A. \& Zanaret, M. (2006). La restructuration du lobule du nez. Annales d'Otolaryngologie et de Chirurgie Cervico-faciale. 123(2), 84-90.

13. Genter, C. (2007). Rekonstruktionsverfahren der Nase nach ablativer Chirurgie und Trauma. Würzburg: Dissertation.

14. Marks, R. (1990). Hauterkrankungen bei älteren Menschen. Berlin: Deutscher Ärzte - Verlag. 